\title{
INFLUENCE OF BAUXITE TAILINGS ON THE STRUCTURE OF THE BENTHIC MACROINVERTEBRATE COMMUNITY IN AN AMAZONIAN LAKE (LAGO BATATA, PARÁ - BRAZIL)
}

\author{
FONSECA, J. J. L. and ESTEVES, F. de A. \\ Laboratório de Limnologia, Departamento de Ecologia, Universidade Federal do Rio de Janeiro, CCS, Bloco A, \\ Cidade Universitária, Ilha do Fundão, CEP 21941-590, Rio de Janeiro, RJ, Brazil \\ Correspondence to: João José Fonseca Leal, Laboratório de Limnologia, Departamento de Ecologia, \\ Universidade Federal do Rio de Janeiro, CCS, Bloco A, Cidade Universitária, Ilha do Fundão, \\ CEP 21941-590, Rio de Janeiro, RJ, Brazil \\ Received June 26, 1998 - Accepted November 9, 1998 - Distributed September 10, 1999
}

(With 4 figures)

\begin{abstract}
This research was developed between 1993 and 1996, aiming to study the structure of the benthic macroinvertebrate community, relating it to some abiotic variables, in an amazonian lake (lago Batata), that received for ten years a great amount of bauxite tailings. The benthic macroinvertebrates were collected with a core and the abiotic variables that were measured were: dissolved oxygen, suspended material, depth, transparency (secchi disc), temperature of the water column and total nitrogen, available phosphorus and organic matter in the sediment. With the use of a Principal Components Analysis (PCA), we were able to show that the sampling sites differed regarding the abiotic variables, especially total-N, available$\mathrm{P}$ and organic matter in the sediment, all of which were found in greater concentrations in the natural areas. The PCA concerning the benthic macroinvertebrate community also distinguished the natural sites from the impacted one. The impacted site was positively grouped with the Ephemeroptera (Campsurus sp.) and the natural sites were grouped together with the Chironomidae, Chaoboridae, Oligochaeta and Bivalvia. The results achieved in this research made clear that the sites under influence of the bauxite tailings had alterations of their abiotic characteristics and of their benthic macroinvertebrate structure.
\end{abstract}

Key words: benthic macroinvertebrates, bauxite tailings, Principal Components Analysis.

\section{RESUMO \\ Influência do rejeito de bauxita sobre a estrutura da comunidade de macroinvertebrados bentônicos em um lago amazônico (Lago Batata, Pará, Brasil)}

Esta pesquisa foi desenvolvida entre 1993 e 1996 com o objetivo de estudar a estrutura da comunidade de macroinvertebrados bentônicos, relacionando-a a algumas variáveis abióticas, em um lago amazônico (lago Batata), que recebeu durante dez anos rejeito de bauxita. Os macroinvertebrados bentônicos foram coletados com um coletor tipo core e as variáveis abióticas medidas foram: oxigênio dissolvido, material em suspensão, profundidade, transparência (disco de secchi), temperatura da coluna d'água e nitrogênio total, fósforo disponível e matéria orgânica do sedimento. A partir da aplicação da Análise de Componentes Principais (PCA) foi possível demonstrar que as estações de coleta foram diferenciadas em relação às variáveis abióticas, principalmente em relação às concentrações de N-total, P-disponível e matéria orgânica do sedimento, sendo encontradas em maiores concentrações nas estações naturais. A PCA referente à comunidade de macroinvertebrados bentônicos também distinguiu as estações naturais da estação impactada. A estação impactada foi positivamente agrupada à Ephemeroptera (Campsurus sp.) e as estações naturais à Chironomidae, Chaoboridae, Oligochaeta e Bivalvia. Os resultados obtidos nesta pesquisa evidenciaram que as áreas impactadas com rejeito de bauxita apresentaram alteração das características abióticas e da estrutura das comunidades de macroinvertebrados bentônicos.

Palavras-chave: macroinvertebrados bentônicos, rejeito de bauxita, Análise de Componentes Principais. 


\section{INTRODUCTION}

The importance of some abiotic variables in the composition and distribution of the benthic macroinvertebrate communities in continental aquatic ecosystems has been discussed by several authors for example Margalef (1983); Prat (1991); Arunachalan et al (1991); Shea (1994); Death (1995); Nessimian (1995), Oertti (1995), especially regarding which of these factors would be limiting to those communities, and in what way these communities would respond to alterations in these variables.

Rosemberg \& Resh (1993) and Callisto (1996) emphasize the fact that the benthic macroinvertebrate communities are abundant and ocur throughout the environment, the methodology for their sampling is established, they exhibit a long life cycle in comparison with other invertebrate communities and they are known to develop differentiated responses to environmental fluctuations, arguing that these are important characteristics for the use of these communities in projects of biomonitoring of aquatic environments. Already in the beginning of the century the benthic communities were used in studies of trophic characterization in temperate lakes (Thienemann, 1920 and 1954). More recently they have been used in biomonitoring projects, especially regarding environments subjected to impacts of an anthropic nature (Schindler, 1987; Rosemberg, 1992; Loeb \& Spacie, 1994; Engle et al., 1994; Callisto \& Esteves, $1996 \mathrm{a}, \mathrm{b}$ ).

From 1979 to 1989 the Batata lake received about 18 millions $\mathrm{m}^{3}$ per year of an effluent formed by bauxite tailings, originated in the process of washing the bauxite (Bozelli, 1994). These tailings were formed in the processing of the bauxite, when the ore was separated from impurities (clay) by decantation with water of the Trombetas River (Esteves et al., 1990). The resulting effluent, rich in very fine clays containing high concentrations of iron, aluminium and silicate oxides, was directly cast into the Batata lake, with the consequent silting up of approximately $30 \%$ of its total area (Lapa \& Cardoso, 1998; Roland, 1991).

In the silted areas of the Batata lake layers of bauxite tailings of up to five meters may be found, over the natural sediment. In these areas the chemical and physical characteristics of the sediment and water column were altered. Therefore, the need to study the sediment of the Batata lake may be underlined, focusing on its abiotic and biotic characteristics, comparing the results of the natural areas with those found in the areas impacted by the bauxite tailings.

The objective of this research was to make clear, through the analysis of the benthic macroinvertebrate community, as well as the analysis of the abiotic variables, what are the consequences of the discharge of bauxite tailings on the benthic compartment of the Batata lake.

\section{STUDY AREA}

The Batata lake is an ordinary amazonian lake, situated in the municipality of Oriximina $\left(1^{\circ}\right.$ $25^{\prime} \mathrm{S}$ and $1^{\circ} 35^{\prime} \mathrm{S}, 56^{\circ} 15^{\prime} \mathrm{W}$ and $56^{\circ} 25^{\prime} \mathrm{W}$ ), State of Pará, Brazil (Fig. 1). One of the main characteristics of the Batata lake is the great fluctuation of the water level, which was distinguished by Esteves et al. (1990) in four phases: filling up, high water, drawdown and low water.

Being in the hydrographic basin of the Trombetas River, to which it is permanently linked, the Batata lake is labeled as a clear-water lake according to Sioli (1950). Its total area is approximately 30 $\mathrm{Km}^{2}$, during the flood (Panosso et al., 1995). The Batata lake is surrounded by an "igapó" forest, that is inundated during the flood period, and as a consequence there is a great input of organic matter (litter) from the forest to the lake. According to Sioli (1985), these fluctuations in the water level are of great importance for the establishment of the aquatic communities, as well as for the determination of the patterns relating to the abiotic variables.

\section{MATERIAL AND METHODS}

Due to the fluctuation of the water level and to the importance of the phenomenon in the dynamics of the amazonian aquatic environments, the sampling events were timed in a way that would follow the four hydrological patterns (filling up, high water, drawdown and low water), from 1993 to 1996.

The sampling sites were established, taking into account the area impacted by the bauxite tailings, and three sites were chosen: site (1), in the impacted area; site (2), in the natural area, in the main body of the lake; and site (3), in another 
natural area, close to the boundary between the lake and the Trombetas River (Fig. 1).

The sediment samples were collected with a core, modified from the model proposed by Ambühl \& Bührer (1975), with a sampling area of $0.025 \mathrm{~m}^{2}$. Only the superficial portion of $10 \mathrm{~cm}$ was sampled, considered by several authors as the most representative for the benthic community (Cecherelli \& Fabbri, 1978; Furse et al., 1984; Callisto, 1996). Were collected six samples where, five samples for the study of the benthic macroinvertebrate community and one to nutrients analysis.
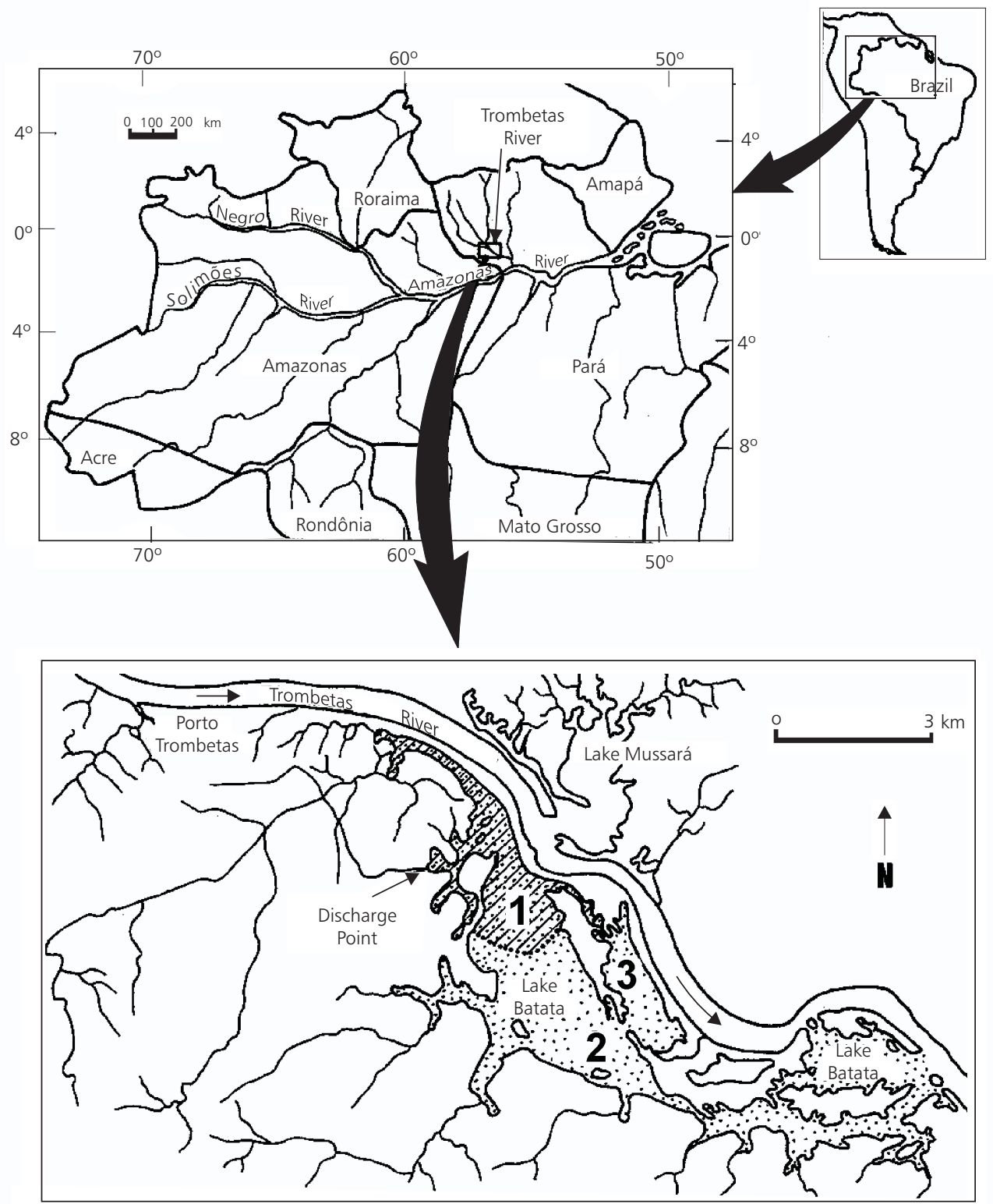

Fig. 1 - Map of the study area and the representation of the sampling sites, site 1 (impacted by the bauxite tailings) and sites 2 and 3 (natural). 
After the collection the benthic samples were kept in plastic bags and fixed with $20 \mathrm{ml}$ of tamponated formaldehyde, and afterwards they were washed over sieves with meshes of $1.0 \mathrm{~mm}$ and $0.5 \mathrm{~mm}$ and sorted under microscope estereoscopic Zeiss (Stemi 2000). For the determination of the organic matter, total nitrogen and available phosphorus the samples were kept in plastic flasks and then dried on a stove at $50^{\circ} \mathrm{C}$. The water column samples were collected with Van Dorn bottles.

In the water column we analyzed: dissolved oxygen, determined by the titulometric method of Winkler, modified by Golterman et al. (1978); temperature (electronic thermometer, FAC 400); transparency (Secchi disk); suspended material, by gravimetry, after filtration in GF/C filters; and depth. In the sediment were analyzed: organic matter (combustion at $500^{\circ} \mathrm{C}$ during four hours); total-N (described by Bezerra, 1987); and available-P (Moreno, 1987).

A Principal Component Analysis (PCA) was performed with the biotic and abiotic data, separately, using the software StatSoft, Statistica, 1991.

\section{RESULTS AND DISCUSSION}

The results of the Principal Component Analysis (PCA) are represented in the Figs. 2 and 3. The variables transparency of the water column (Secchi) and depth were responsible for a great deal of the positive variation of the axis 1 while dissolved oxygen, suspended material and temperature were responsible for the negative variation in that axis. The axis 2 was negatively explained by total phosphorus, organic matter and total nitrogen, these being the variables associated with the sediment. These two axes explain $66.11 \%$ of total variance of the data .

The distribution pattern presented (Fig. 2) by the abiotic variables shows that the variables transparency (Secchi) and depth are positively linked, while oxygen, temperature and suspended material are negatively linked to the former. This result may be accounted for by the fact that in the high water period, with a greater depth (ranging from 5.5 to $9 \mathrm{~m}$ ), a smaller effect of the turbulence of the water column on the sediment is observed, along with a diluted effect (Esteves et al., 1994). Therefore higher values of transparency (Secchi depth) and lower values of temperature, dissolved oxygen and suspended material are found. In the low water period, when the Batata lake is shallower $(0.3$ to $3.5 \mathrm{~m})$, there is a greater influence of currents and their turbulence, caused by winds, in the resuspension of the sediment, especially in the areas impacted by the bauxite tailings, causing higher values of suspended material. Due to the lower depth, favoring a greater homogenization of the water column by the winds, the highest temperature and dissolved oxygen saturation values are observed.

The projection of the sampling events relating them to the abiotic variables (Fig. 2), showing that the second axis was responsible for the separation of the sampling sites. It can be observed that the sampling events in the site (1) (impacted) were projected mostly in the negative quadrant of the second axis, showing that this site, independently of the hydrological period, had the lowest concentrations of available phosphorus, organic matter and total nitrogen. The sites (2) and (3) (natural) were projected positively in relation to these variables, demonstrating a higher concentration of these nutrients in the natural areas. In the sites (2) and (3) the maximum values found regarding the organic matter were $22.5 \% \mathrm{DW}$ and $24.0 \% \mathrm{DW}$, respectively, 207 $\mathrm{ppm}$ and $383 \mathrm{ppm}$ regarding available phosphorus, respectively, and $6300 \mathrm{ppm}$ and $7100 \mathrm{ppm}$ regarding total nitrogen, respectively.

These values were higher than those found in the impacted area (site 1), where the concentrations were around $19.58 \% \mathrm{DW} ; 44 \mathrm{ppm}$; and $3100 \mathrm{ppm}$, respectively for organic matter, available-P and total-N. This result may be attributed to the composition of the bauxite tailings, rich in inorganic matter, fine clays and extremely poor regarding nutrients.

Among the groups of organisms found in the benthic macroinvertebrate community in the Batata lake, Chironomidae, Chaoboridae, Oligochaeta and Ostracoda were the ones with the greatest density in the three sampling sites. However, the values observed for these same groups in the impacted area were lower than the values observed in the natural areas (sites 2 and 3). Campsurus sp. (Ephemeroptera; Polymitarcidae) was found almost totally restricted to the area impacted by the bauxite tailings, while Bivalvia was found only in the natural areas.

The Principal Components Analysis (PCA) for the taxonomic groups (Fig. 3) made clear that Oligochaeta, Chironomidae, Bivalvia, Ostracoda and Polymitarcidae were responsible for the grea- 
test part of the variation along the axis $1(25.6 \%)$, with Ephemeroptera representing a great deal of the positive variation and the other groups contributing for the negative variation. These groups are projected on opposite sides, meaning that where one of them does occur the other does not, or only does so with very low densities. Regarding the axis $2(16 \%)$, it is strongly explained by Nematoda and Copepoda (the two axis answer for $41.6 \%$ of the total variation).
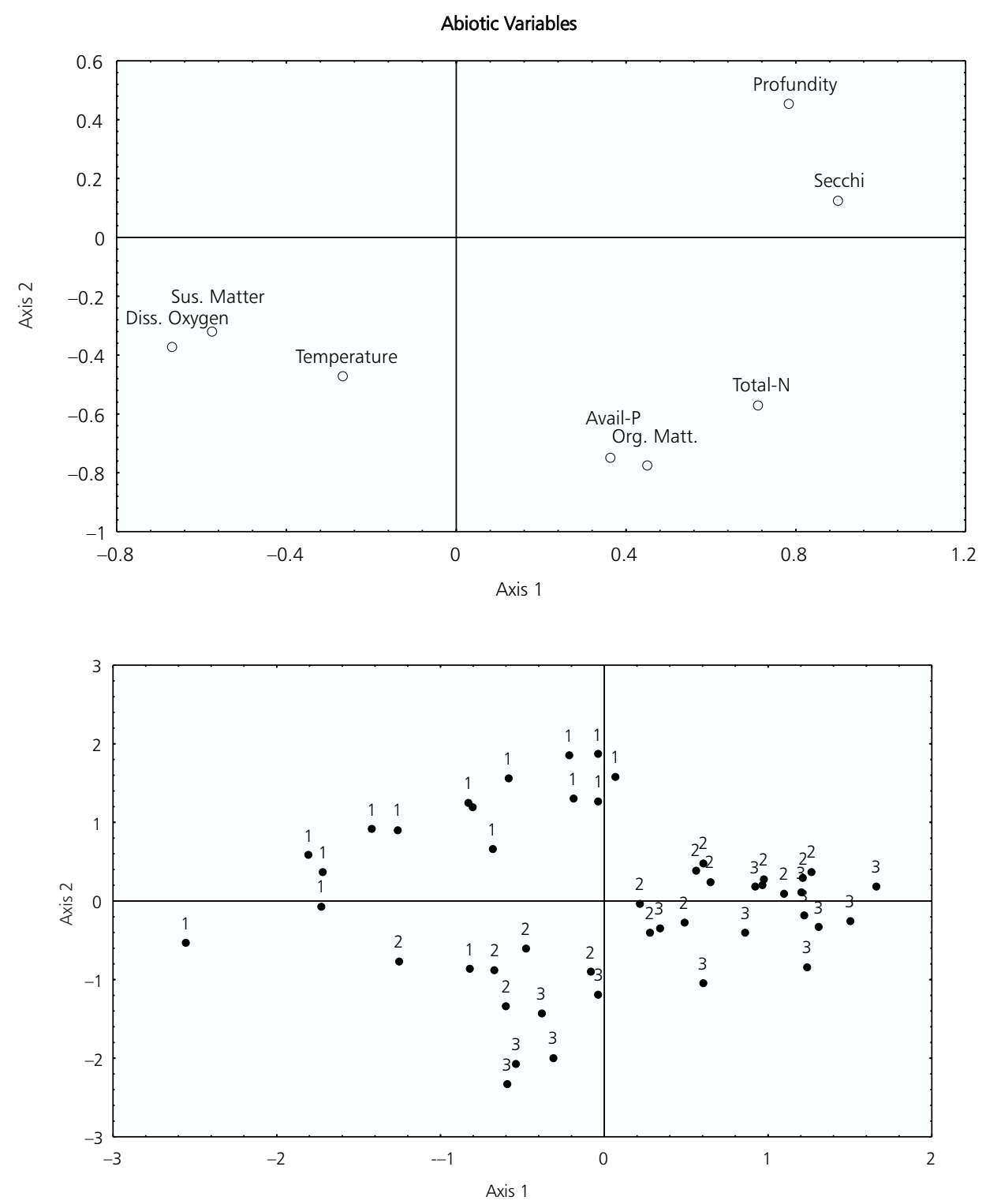

Fig. 2 - Principal Components Analysis, representing the distribution of the impacted (1) and natural (2 and 3) sites related to the abiotic variables dissolved oxygen (Diss. Oxygen), suspended matter (Sus. Matter), temperature, transparency (Secchi), depth, available phosphorus (Avail-P), organic matter (Org. Matt.) and total nitrogen (Total-N) regarding the axes 1 and 2 which explain $68.24 \%$ of the total variation of the data. 

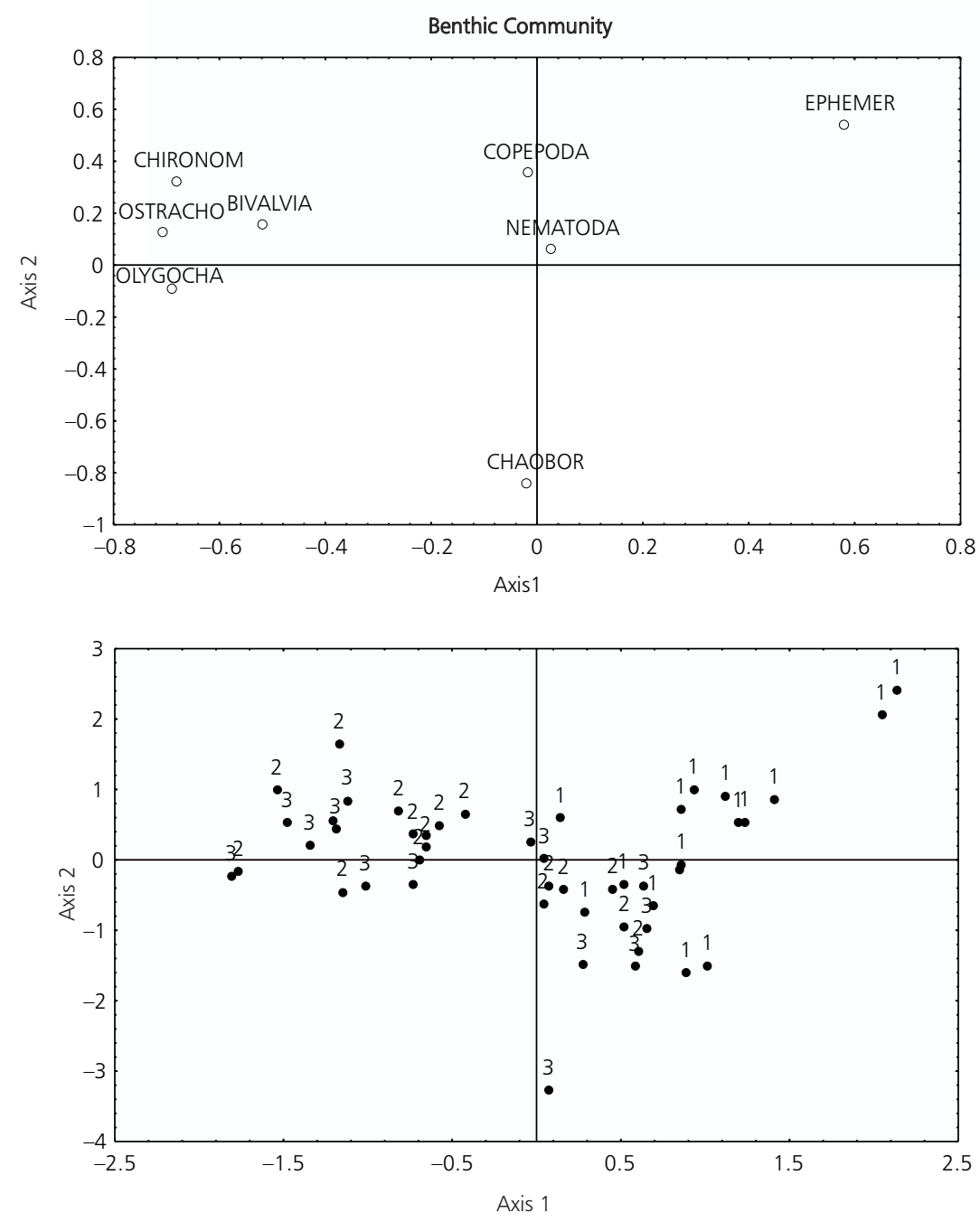

Fig. 3 - Principal Component Analysis, where the impacted (1) and natural (2 and 3) sites are projected in relation to the taxonomic groups, Oligochaeta, Chironomidae, Chaoboridae, Copepoda, Bivalvia, Ostracoda, Nematoda and Ephemeroptera, the two first axes being shown, corresponding to $42.9 \%$ of the total variation of the data.

In the same figure, where the sampling events in each site are projected related to the taxonomic groups, it can be observed that the events related to the impacted area were again grouped apart from the natural sites. The impacted area (site 1) is strongly and positively grouped with the group Ephemeroptera (Campsurus sp.), while the natural sites ( 2 and 3 ) were grouped negatively to this group and positively to Oligochaeta, Bivalvia, Ostracoda and Chironomidae. These results are in accordance with the results found by Callisto \& Esteves (1996a; b) and Fonseca et al. (1998), where these authors observe that Ephemeroptera (Campsurus sp.) is a group that is almost completely restricted to the areas with a very fine sediment, as the one found in the impacted area of the Batata lake. This genus was found in other "várzea" lakes in the Amazonian region (Irmler, 1975; Fittkau et al., 1975) and, according to Nolte (1988), the genus Campsurus exhibits characteristics of pioneering organisms in areas with a very fine sediment and muddy waters, and this may explain the presence of this group in the impacted area almost exclusively. 
Besides that Nolte (1987) underlines the role of one species of this genus (Campsurus notatus) in bioturbation processes in another amazonian "várzea" lake. Therefore we may emphasize the importance of this group regarding the alteration of the characteristics of the sediment, in the impacted areas of Batata lake, through the bioturbation process.

Chironomidae, Chaoboridae and Oligochaeta were dominant in the natural areas, their occurrence being associated with the highest levels of organic matter, total-N and available-P in the sediment.

Regarding the mean of total densities of the benthic macroinvertebrate community in each sampling site during all phase of the inundation cycle, it may be observed (Fig. 4) that the densities found in the impacted area $\left(X=242.6 \mathrm{ind} / \mathrm{m}^{2} \pm 121.12\right)$ were significantly different (Kruskal-Wallis, $\mathrm{p}<$ $0.001)$ from the natural sites 2 and $3,(X=525.9$ ind $\left./ \mathrm{m}^{2} \pm 191.9\right)$ and $\left(X=540.3 \mathrm{ind} / \mathrm{m}^{2} \pm 270.04\right)$ respectively. This fact reinforces the idea that the bauxite tailings altered the distribution of the organisms of the benthic macroinvertebrate community in Batata lake.

However, if we compare the data obtained for density in this research with those found by Callisto \& Esteves (1996b) we may observe that the densities found in this research in the impacted area were higher than those found by those authors, suggesting a recolonization of these areas by the other groups of benthic macroinvertebrates, reflecting a possible improvement of the ecological conditions in the impacted area.

This results corroborate the hypothesis that the discharge of bauxite tailings in the Batata lake provoked alterations in some limnological characteristics (especially those related to the sediment) in the area under the influence of the tailings. These alterations did modify the ecological conditions of the area, resulting in the change of the structure of the benthic macroinvertebrate community.

The distribution of Campsurus sp., almost restricted to the impacted areas, as well as the high densities found, suggest that this species, being adapted to the conditions imposed by the presence of the bauxite tailings, with low nutrient and organic matter concentrations and high concentration of fine particles, is a good indicator of the ecological characteristics in the impacted areas.

As Campsurus sp. is acknowledgedly important in the bioturbation process in fine sediments, more in-depth studies are necessary on the dynamics of this population and its real contribution to the bioturbation process in Batata lake, so that we may better understand how great is the contribution of this population to the alteration of the ecological characteristics of the areas impacted with bauxite tailings.

Mean Density (ind $/ \mathrm{m}^{2}$ )

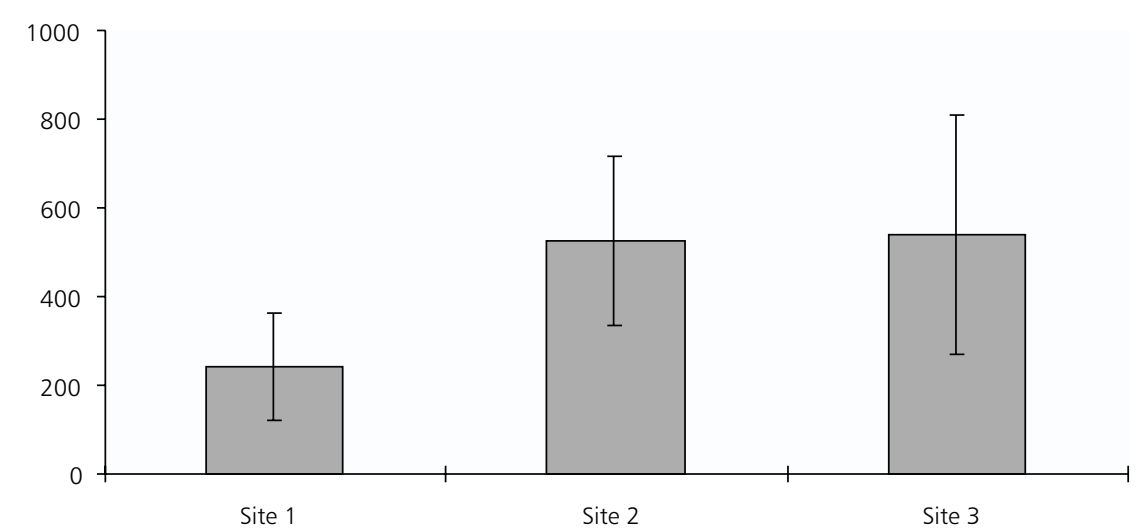

Fig. 4 - Mean and standard deviation of total density of organisms (ind $/ \mathrm{m}^{2}$ ), obtained in the impacted area (site 1$)$ and in the natural areas (sites 2 and 3), of all periods of the inundation cycle (filling up, flood, drawdown and low water), from 1993 to 1996. 
Acknowledgements - The authors extend their thanks to the colleagues of the Laboratory of Limnology of UFRJ for the help with the chemical analyses, to Mineração Rio do Norte for the funding, to CNPq for the research scholarships granted, to Prof. Dr. Marcos Callisto, MSc. Cleber Palma and MSc. Edelti Albertoni for the invaluable criticism, and to Reinaldo Bozelli, Fábio Roland and Alex Prast for the great help in the field work.

\section{REFERENCES}

AMBÜHL, H. \& BÜHRER, H., 1975, Zur technik der Entnahme Ungestörter Grossproblen von Seesedimenten: ein Nerbessertes Bohrlot. Scheweiz. Z. Hydrol., 37: 175-186.

ARUNACHALAN, M., MADHUSOODANA NAIR, K. C., VIJVERBER, J., KORTMULDER, K. \& SURIYANARAYANAN, H., 1991, Substrate selection and seasonal variation in densities of invertebrates in strem pools of a tropical river. Hydrobiologia, 213: 141-148.

BEZERRA, M. A. O., 1987, Contribuição ao estudo limnológico da Represa de Três Marias (MG) com ênfase no ciclo do nitrogênio. PPG-ERN, UFSCar, São Carlos, Brasil. M.Sc.-thesis: $135 \mathrm{p}$.

BOZELLI, R. L., 1994, Zooplankton community density in relation to water level fluctuations and inorganic turbidity in an Amazonian lake, "Lago Batata", State of Pará, Brazil. Amazoniana, XIII(1/2): 17-32.

CALLISTO, M. F. P., 1996, Macroinvertebrados bentônicos em quatro ecossistemas lóticos amazônicos sob influência das atividades de uma mineraração de bauxita (Porto Trombetas, Pará). PPGB Inst. Carlos Chagas Filho, UFRJ, Rio de Janeiro, Brasil. Ph.D.-thesis: 140p.

CALlisto, M. F. P. \& ESTEVES, F. A., 1996a, Composição granulométrica do sedimento de um lago amazônico impactado por rejeito de bauxita e um lago natural (Pará, Brasil). Acta Limnol. Bras. 8: 115-126.

CALLISTO, M. F. P. \& ESTEVES, F. A., 1996b, Macroinvertebrados bentônicos em dois lagos amazônicos: Lago Batata (um ecossistema impactado por rejeito de bauxita) e Lago Mussurá (Brasil). Acta Limnol. Bras., 8: 137-147.

CECCHERELLI, V .U. \& FABBRI, G. G., 1978, Sampling efficiency types of cores on meiofauna of muddy bottom. Arch. Oceanogr. Limnol., 19: 85-98.

DEATH, R. G., 1995, Spatial patterns in benthic invertebrate community structure: products of habitat stability or are they habitat specific? Freshwater Biology, 33: 455-467.

ENGLE, V. D., SUMMERS, J. K. \& GASTON, G. R., 1994, A benthic index of environmental condition of Gulf of Mexico estuaries. Estuaries, 17(2): 372-384.

ESTEVES, F. A., BOZELLI, R. L. \& ROLAND, F., 1990, Lago Batata: Um laboratório de limnologia tropical. Ciência Hoje, 11(64): 26-33.

ESTEVES, F. A., THOMAZ, S. M. \& ROLAND, F., 1994, Comparison of the metabolism of two floodplain lakes of the Trombetas River (Pará, Brazil) based on a study of diel variation. Amazoniana, XIII(1/2): 33-46.
FITTKAU, E. J., IRMLER, U., JUNK, W. J., REISS, F. \& SCHMIDT, G. W., 1975, Productivity, biomass and population dynamics in Amazonian water boldies. Amazonian Aquatic Systems, Sprin.-Verlag, New York Inc., pp. 289311.

FONSECA, J. J. L., CALLISTO, M. F. P. \& GONÇALVES J. F. Jr., 1998, Benthic macroinvertebrate community structure in Amazonian lake impacted by bauxite tailings (Pará, Brazil). Verh. Int. Ver. Limnol., 26: 2053-2055.

FURSE, M. T., MOSS, D., WRIGHT, J. F. \& ARMITAGE, P. D., 1984, The influence of sasonal and taxonomic factors on the ordination and classification of running-water sites in Great Britain and on the prediction of their macroinvertebrate communities. Freshwater Biology, 14: 257-280.

GOLTERMAN, H. L, CLYMO, R. S. \& OHNSTAD, M. A. M., 1978, Methods for physical and chemical analysis of freshwater. Londres, Blackwell Scientific Publication, $217 \mathrm{p}$.

IRMLER, U., 1975, Studies of the aquatic soil invertebrates in three inundation forests of Central Amazonian. Amazoniana, 5: 337-409.

LAPA, R. P. \& CARDOSO, W., 1988, Tailings disposal at the Trombetas bauxite mine. Proc. 117 th. TMS Annual Meeting, Phoenix (ed. Larry), pp. 65-76.

LOEB, S. L. \& SPACIE, A., 1994, Biological monitoring of aquatic systems. Florida, Lewis Publishers, 381p.

MARGALEF, R., 1983, Limnología. Ediciones Omega, S.A, Barcelonas. 951p.

MORENO, I. H., 1987, Contribuição ao estudo do ciclo do fósforo na represa de Três Marias. São Carlos, PPGERN, UFSCar. M.Sc-thesis: 160p.

NESSIMIAN, J. L., 1995, Abundância e biomassa de macroinvertebrados bentônicos em um brejo de dunas no litoral do Estado do Rio de Janeiro. Rev. Brasil. Biol., 55(4): 661-683.

NOLTE, U., 1987, Campusurus notatus (Polymitarcidae, Ephemeroptera), a bioturbator in várzea lakes. Amazoniana, $X(2)$ : 219-222.

NOLTE, U., 1988, Small water colonization in pulse stable (várzea) and constant (terra firme) biotopes in the Neotropics. Arch. Hydrobiol., 113(4): 541-550.

OERTTI, B., 1995, Spatial and temporal distribution of the zoobenthos community in a woodland pond (Switzerland). Hydrobiologia, 300/301: 195-204.

PANOSSO, R. F., MUEHE, D. \& ESTEVES, F. A., 1995, Morphological characteristics of an Amazon floodplain lake (Lake Batata, Pará State, Brazil). Amazoniana, XIII(3/4): 245-258.

PRAT, N., 1991, Present trends in river studies. Oecologia Aquatica, 10: 1-12.

ROLAND, F., 1991, Influência do pulso de inundação e do efluente de lavagem de bauxita sobre a dinâmica do fósforo, nitrogênio e carbono em um lago amazônico ( $L$. Batata, PA). UFSCar/PPG-ERN, São Carlos, Brazil. M.Sc.thesis: $128 \mathrm{p}$. 
ROSEMBERG, D. M., 1992, Freshwater biomonitoring and Chironomidae. Wetherlands Journal of Aquatic Ecology, 26(2-4): 101-122.

ROSEMBERG, D. M. \& RESH, V. H., 1993, Freshwater biomonitoring and benthic macroinvertebrates. Ed. Chapman \& Hall, 488p.

SCHINDLER, D. W., 1987, Detecting ecosystem responses to anthropogenic stress. Can. J. Fish. Aquat. Sci. 44 (Suppl. 1): 6-25.

SHEA, S. S., 1994, The effects of water quality, epilithic algae and organic matter on communities of stone-dwelling invertebrates in a Hong Kong river. Mitt. Internat.Verein. Limnol., 24: 327-336.
SIOLI, H., 1950, Das wasser im Amazonasgebiet. Forsch. Fortschr, 26: 274-280.

SIOLI, H., 1985, Amazônia: fundamentos da ecologia da maior região de florestas tropicais. Trad. Johan Becker, Petrópolis, Editora Vozes, 72p.

THIENEMANN, A., 1920, Biologische Seetypen und die Gründung einer hydrobiologischen Anstfalt am Bodensee. Arch. Hydrobiol., 13: 347-370.

THIENEMANN, A., 1954, Chironomus Leben, Verbreitung und Wirtschaftliche Bedeutung der Chironomiden. Die. Binnengewasser, 20, 834p. 